\title{
Water Analyses, Eco-Balance and Socio-Demographic Analyses as Prerequisites for Solutions of the Sewage Treatment Problems in Rural Areas
}

\author{
Christian 0pp' ${ }^{1}$, Bastian Ziebolz ${ }^{2}$ \\ ${ }^{1}$ Department of Hydrology and Soil Science, Faculty of Geography, University of Marburg, Marburg, Germany \\ ${ }^{2}$ KLT Consult, Hannover/Soest, Germany \\ Email: opp@staff.uni-marburg.de
}

Received November 2015

\section{Abstract}

The implementation of the EU-water framework directive (EU-WFD) demands a financeable and adaptable sewage treatment, creating a need for action especially in rural areas, where the "good ecological status" is often not reached even though the sewage works fulfill the legal minimum requirements. Therefore the construction of new, more efficient wastewater treatment plants is advisable. Due to the precarious financial situation in most rural areas, many municipalities can however not master the necessary funds for an improved waste water infrastructure. A large part of the costs would have to be shouldered by the local population in the form of additional sewage levies, leading to massive socio-economic strain. Hence, different solutions, which are tailored to the socio-economic, demographic and environmental characteristics of rural areas and fulfill the legal requirements, need to be developed. One possible approach is presented in the form of the Dirlammen case study (municipality Lautertal, Hesse, Germany). It consists of 1) biological and physicochemical analyses of the waste waters, 2) a modified eco-balance for the construction of a new sewage works and 3) socio-economic and demographic analyses of the population. It serves as a tool for the assessment of the influencing ecological, socio-economic and demographic factors on the sewage problems in rural areas. These findings can easily be transferred to other rural areas with a similar configuration and thus deliver the basis for a generally applicable approach to these problems. The results of the comprehensive analysis have shown for the municipality Dirlammen/Lautertal that the continued operation of the existing pond sewage plant is, with regards to the ecological, socio-economic and demographic points of view, preferable to the construction of a new waste water treatment plant. With regard to the sustainability principles of the sewage treatment and the objectives of the EU-WFD, existing sewage works should be operated for as long as the sewage treatment is feasible within technical and legal boundaries. With the construction of new facilities on the other hand, the expected improvement of the water quality has to be weighed against the ecological impairments caused by the construction itself. Rural waste water plans have to be developed for the long-term, taking not only the ecology into account but also the demographic change. Possible approaches in this regard could be a shift towards a decentralized waste water treatment concept and-even more important-improvements of the river morphology. But also the reduction of the diffuse pollution from agricultural sources should be considered for the 
development of strategies for the improvement of the ecological state. Short-term optimization measures in the existing sewage works might also improve the water quality until the long-term development plans can be implemented. In particular the challenges of the demographic change and linked with that the changing requirements for the rural waste water treatment must be addressed by any future plans. Only with the help of such a comprehensive approach the dangers of bad planning and unacceptable socio-economic burdens can be minimized.

\title{
Keywords
}

\author{
Water Analyses, Eco-Balance, Sewage Treatment Plant, Socio-Economic and \\ Demographic Analyses
}

\section{Introduction and Problem Setting}

The EU-water framework directive (EU-WFD) demands a "good ecological state" for all ground and surface waters (rivers, lakes, transitional waters, and coastal waters) within the European community by the year 2015. The EU-WFD also has defined the "good ecological status" as values, determined by the chemical quality conditions (standards specify maximum concentrations for specific water pollutants), the biological quality conditions (by indicator species such as fish, benthic invertebrates, and aquatic flora) and the physicochemical quality conditions (temperature, oxygenation and nutrient concentrations) [1]. Besides these criteria the improvement of the hydro-morphological conditions of the water bodies will play an important role [2]. The water quality of the rivers is strongly influenced by diverse point and nonpoint impacts. Due to the fact that nonpoint impacts are extremely difficult to manage, the main activities to improve the water quality of the impacts are directed towards the reduction of the harmful pollutants from point sources.

Results of the above mentioned indicator monitoring often show problems in rural areas. Reasons for these problems are connected to the mostly small size of the rural rivers and creeks, which are less able for self-purification and dilution processes on the one hand and with the most common pond sewage treatment on the other hand. Pond sewage treatment plants are the most common technology for wastewater treatment in rural areas in Germany because they are based on the microbial self-purification processes and thus are especially cost-effective [3] [4]. Monitoring of the pond sewage treatment plants however show that they have purification deficits, and thus are often responsible for the a impairment of the water quality in little rivers and creeks downstream of the water-input coming from the pond sewage treatment. Due to this fact the construction of modern wastewater treatment plants is on the agenda. However, the rural population has already to pay above average per capita fees for the maintenance and operation of these wastewater treatment facilities and for the rehabilitation of the household's sewage pipe system. Additional payments of the rural population for the construction of a new sewage treatment plant (STP) are not reasonable, especially as the population density in rural areas is decreasing. That is why the investments for the construction of a new sewage treatment plant cannot be covered by the rural communities.

\section{Study Area}

The same problem situation was found in the community of Lautertal, in the Vogelsberg District, within the Federal State of Hesse (Germany). Seven villages with a total population of 2424 are part of this community. In one of the community parts, the location Dirlammen (419 inhabitants), the situation was studied in detail. The existing pond based STP of Dirlammen is operating since 1887 based on self-purification without denitrofication and nitrification, fulfilling all legal minimum requirements. The monitoring of pollutant input into the nearby creek shows an excess of the tolerable input, especially of the tolerable $\mathrm{NH}_{3}$-concentration, which affects eutrophication.

\section{Objectives and Research Approach}

Based on the problem presented above, multiple research questions, objectives, and methods were selected for this study (Figure 1). 


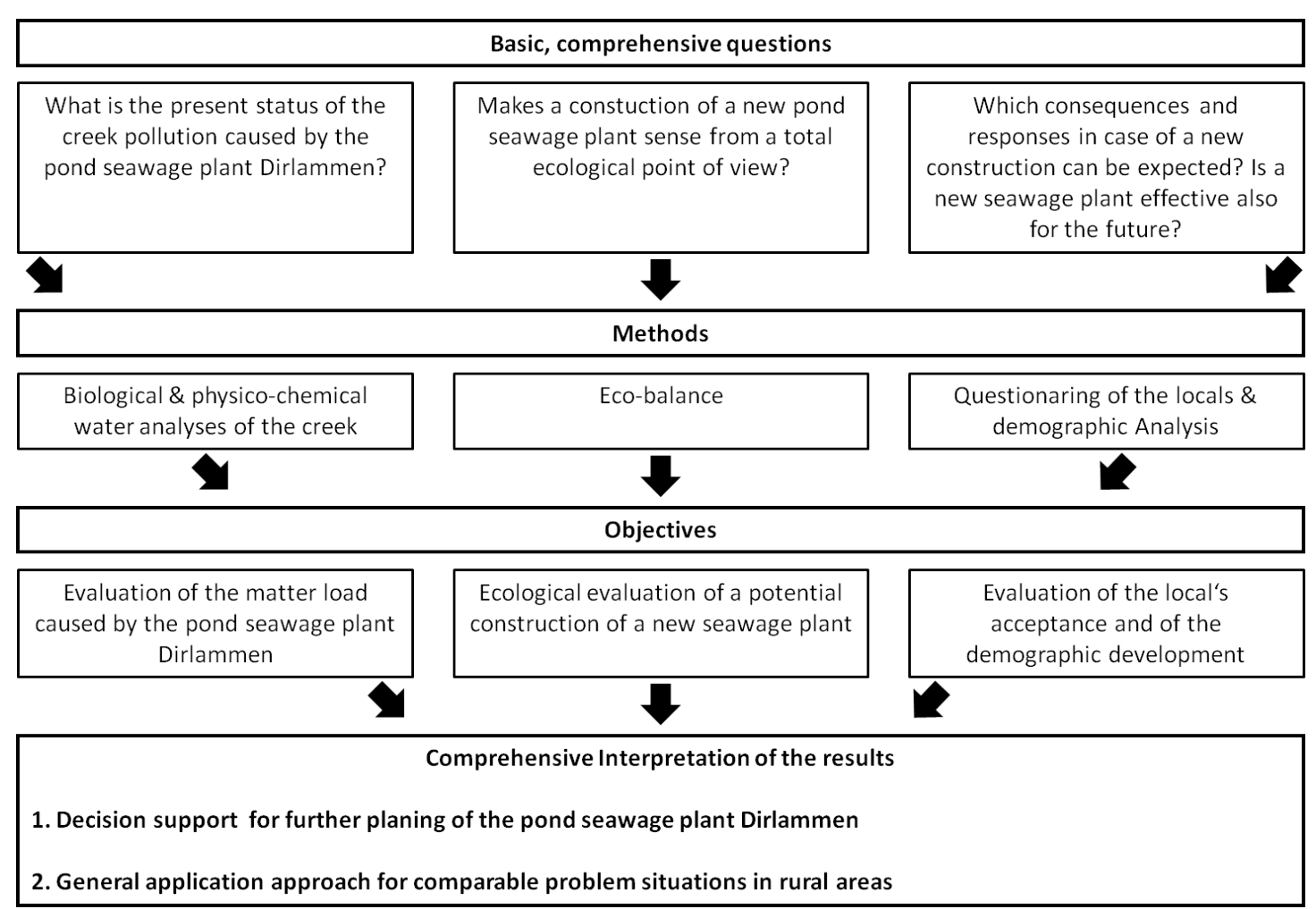

Figure 1. Concept and objectives of the Lautertal (Dirlammen) study.

\section{Methods}

Discharge, water temperature, $\mathrm{pH}$-value, and electric conductivity measurements as well as saproby index, $\mathrm{NH}_{3}$, $\mathrm{NH}_{4}, \mathrm{NO}_{2}, \mathrm{NO}_{3}$ concentrations, oxygen saturation, oxygen content, total phosphor concentration determinations were carried out at four times during spring (March 22, April 26) and summer (June 21, July 12) 2010 at four sampling sites (SaSi) along the Brenderwasser creek near Dirlammen: (1) $200 \mathrm{~m}$ above of the STP input, (2) directly $50 \mathrm{~m}$ downstream of the STP input, (3) $900 \mathrm{~m}$ and (4) $2200 \mathrm{~m}$ downstream of the STP input. All analyses were carried out using WTW techniques [5] according to the federal water agreement [6].

To determine the environmental effects of the construction of a new sewage treatment plant in comparison to the existing pond sewage treatment, the eco-balance (or a life cycle assessment) method [7] was used. This life cycle assessment comprises the determination of the costs for the production of a new STP, including the costs for material, and the costs for the operation. These analysis and evaluation was carried out with the help of the computer software GEMIS (Global Emission Model Integrated System), Version 4.5. Different process modules for production and energy use have been analyzed according to [8]. Furthermore the eco-balance includes the comparison and evaluation of the additional load by selected environmental side effects, such as the greenhouse effect (with a very high ecological priority), the summer smog and the acidification (both with a high ecological priority), the energy demand and direct disturbances of the aquatic ecosystem (with a moderate ecological priority). All these parameters have been analyzed both for a new STP and the existing pond STP for operating times of 15 and 30 years. For the assessment of the age-related and employment-related population structure and their monetary potential to pay for higher wastewater treatment costs, socio-economic questioning [8] and interviews [9] [10] have been carried out.

\section{Results and Discussion}

\subsection{Physicochemical and Biological Measurements}

Results of the discharge measurements show that the value for March of $668.0 \mathrm{l} / \mathrm{s}$ represents a 27 times higher discharge than the long-term average of $25.0 \mathrm{l} / \mathrm{s}$, while the April (9 l/s), June (5 l/s) and July (1 l/s) measure- 
ments represent low water situations. The different discharges are a good prerequisite for evaluation of the dilution effects. The water temperature increased from March $\left(7.3^{\circ} \mathrm{C}\right)$, April $\left(15.2^{\circ} \mathrm{C}\right)$, June $\left(12.4^{\circ} \mathrm{C}\right)$ to July $\left(19.9^{\circ} \mathrm{C}\right)$.

The saprobic index values show a good ecological quality at SaSi's 1, 3 and 4, while SaSi 2 has only a moderate saprobic index value. Responsible for this is the mass occurrence of Asselus aquaticus, an indicator species, who nourishes on decomposed substances, which occur in the surrounding of the STP outflow. Higher $\mathrm{NO}_{3}$ concentrations during March are a result of de-icing salt input or of the input by melting snow into the creek. $\mathrm{NH}_{3}$ and $\mathrm{NH}_{4}$ have low or very low values during March, April and June at all SaSi's, but high (15 times higher values in April) and 31 times higher during the July measuring campaign at SaSi 2, The samplings in April and June were realized under comparable water temperature and low discharge conditions.

The electric conductivity, an indicator of the sweeping ion concentration has an average value of about 350 $\mu \mathrm{S} / \mathrm{cm}$ at the SaSi (1), and shows a strong increasing value at SaSi (2) near by the STP outflow, after which it is decreasing continuously in the direction of flow until SaSi (4), where it achieves the average value again. All pH values at all SaSi's and during all measuring dates ranged between 7.2 and 8.0, which means that they are unproblematic. The lowest $\mathrm{pH}$ values were determined in March and in June nearby the STP outflow. The highest phosphorus values were measured during all sampling dates at SaSi (2). While the phosphorus concentrations during March, April and June were fluctuating here between 0.3 and $0.6 \mathrm{mg} / \mathrm{l}$, the corresponding July value during the extreme low water situation is with $3.2 \mathrm{mg} / \mathrm{l}$ quite higher. This is a consequence of the low dilution capacity during the very low discharge. Also the values of oxygen content and oxygen saturation have their lowest extremes at SaSi (2), near the STP outflow. In March at all SaSi's registered the highest $(12.0 \mathrm{mg} / \mathrm{l}$ and $100 \%$ ) and in July the lowest $\mathrm{O}_{2}$ values.

\subsection{Eco Balance}

Due to the fact that the costs of a newly constructed STP are very high, they are not comparable with the further ongoing operation of an old pond STP. However, it is interesting to study the environmental side-effects of an old STP and comparing them with a new one. All a.m. ecologic side-effects without the exception of the direct disturbances of the aquatic ecosystem have a distinct additional load through the construction and operation of a new STP. The additional load by construction and operation of a STP is regarding the greenhouse effect ( $\mathrm{CO}_{2}$-equivalents) $299 \%$ (after a 15 years operation) and 184\% (after a 30 years operation) higher than the further operation of the old STP. The according values regarding the summer smog effect are $852 \%$ (after a 15 years operation) and $461 \%$ (after a 30 years operation) higher than the further operation of the old STP. The according values regarding the acidification ( $\mathrm{SO}_{2}$-equivalents) are 567\% (after a 15 years operation) and 318\% (after a 30 years operation) higher than the further operation of the old STP. Also the values for the energy demand are $212 \%$ (after a 15 years operation) and $141 \%$ (after a 30 years operation) higher than the further operation of the old STP. But the longer the operation time of the new STP is, the smaller are these additional loads. Only the direct disturbances of the aquatic ecosystem are $18 \%$ higher through the further operation of the old pond STP compared to a new one.

\subsection{Socio-Economic and Demographic Developments}

$54 \%$ of all inhabitants (total 419) of the village Dirlammen are retired. 17\% are working in the service sector, $13 \%$ in the public survey sector, $10 \%$ in the production sector, $3 \%$ in the construction sector, and $3 \%$ in agriculture. This is a typical employment structure for rural areas in Germany. 30 domestic homes or 1/3 of the inhabitants took part in the survey. 93\% of all interviewed persons expressed their protest against additional costs caused by a new STP. 3\% would leave the village as they could not afford the additional financial burden. $4 \%$ did not answer this question. According to the latest demographic development, a continuous population decrease can be expected for the future. This implicates not only higher wastewater costs for the smaller number of inhabitants. This also implicates an under-utilization of a new STP and thus questions the need for a new wastewater treatment facility.

\section{Conclusion}

Summing up the above mentioned results, a continuation of the pond STP operation is recommendable. It seems 


\begin{tabular}{|c|c|c|}
\hline \multicolumn{3}{|c|}{ Methods } \\
\hline $\begin{array}{l}\text { Biological \& physico-chemical } \\
\text { water analyses of the creek }\end{array}$ & Eco-Balance & $\begin{array}{l}\text { Questionaring of the locals \& } \\
\text { demographic analysis }\end{array}$ \\
\hline \multicolumn{3}{|c|}{ Results } \\
\hline $\begin{array}{l}\text { - The influence of the pond } \\
\text { seawage plant was proved over a } \\
\text { flowing distance of } 900 \mathrm{~m} \\
\text { - Critical load only near the direct } \\
\text { outflow during low water periods } \\
\text { - No chronic ammoniac load } \\
\text { - With exception of the outflow } \\
\text { part } \rightarrow \text { target of the EU-WFD } \\
\text { fulfilled }\end{array}$ & $\begin{array}{l}\text { - Significant additional load caused by } \\
\text { construction and operation of a STP } \\
\text { - Few improvement of the water } \\
\text { quality in consequence of a new STP } \\
\text { - long as possible operation of a SWP } \\
\text { from a ecological and economical } \\
\text { point of view is bebeficial }\end{array}$ & $\begin{array}{l}\text { - High financial pressure by a new } \\
\text { STP } \\
\text { - Protest and legal steps as a } \\
\text { response to a new STP } \\
\text { - Aging and decreasing number of } \\
\text { the population } \\
\text { - Future under-utilization of a new } \\
\text { STP }\end{array}$ \\
\hline \multicolumn{3}{|c|}{ Comprehensive Interpretation of the results } \\
\hline $\begin{array}{l}\text { - Further operation of the pond se } \\
\text { - Optimizing of the pond seawage } \\
\text { - Development of a long-term eco } \\
\text { - Demand of a new evaluation sys } \\
\text { in consideration }\end{array}$ & $\begin{array}{l}\text { ge treatment plant Dirlammen } \\
\text { t Dirlammen as a short-term alternative } \\
\text { ic seawage treatment concept } \\
\text { which besides ecologic also socio-econc }\end{array}$ & and demographic conditions takes \\
\hline
\end{tabular}

Figure 2. Concept and objectives of the Lautertal (Dirlammen) study.

to be more effective to improve the purification technology of the existing pond STP. The elaboration of a longterm affordable wastewater treatment concept is a present task. For decision finding of the right wastewater treatment for rural areas, socio-economic and demographic analyses have to be taken into consideration besides water analyses and eco-balance application (Figure 2).

\section{Acknowledgements}

The authors want to thank the administration and the inhabitants of the Dirlammen village within the Lautertal community for their cooperation, and Frank Reißig for his advices regarding the eco-balance application.

\section{References}

[1] European Waterframework Directive (EU-WFD) (2000) Directive 2000/60/EC of the European Parliament and the Council of 23 October 2000 Establishing a Framework for Community Action in the Field of Water Policy. Official Jounal L327, 22/12/2000 P 0001-0073.

[2] Groll, M. and Opp, Ch. (2007) Gewässerbettmorphologie und Habitate in einem renaturierten Abschnitt der Lahn. Exemplarische Anwendung des TRiSHa-Verfahrens. Naturschutz und Landschaftsplanung, 39, 369-376.

[3] Landesamt für Umweltschutz Sachsen-Anhalt (LfU) (2006) Abwasserteichanlagen zur kommunalen Abwasserreinigung (Hinweise zu Planung, Bau, Betrieb und Optimierung). Fachbereich 2 Abfallwirtschaft, Bodenschutz, Anlagentechnik Wasserwirtschaft, Halle.

[4] Borchard, D. and Menadi, F. (2001) Empfehlungen für die Errichtung und den Betrieb von belüfteten Teichkläranlagen. Institut für Gewässerforschung und Gewässerschutz (IAG) \& Universität Gesamthochschule Kassel.

[5] http://www.wtw.de/downloads/manuals/

[6] LAWA-AO (2007) Landesarbeitsgemeinschaft Wasser-Ausschuss Oberirdische Gewässer und Küstengewässer Rahmenkonzeption Monitoring. Teil B: Bewertungsgrundlagen und Methodenbeschreibung. Arbeitspapier 2. Hintergrundund Orientierungswerte für physikalisch-chemische Komponenten.

[7] Klöpfer, W. and Grahl, B. (2009) Ökobilanz (LCA)—Ein Leitfaden für Ausbildung und Beruf. Weinheim. http://dx.doi.org/10.1002/9783527627158 
[8] Institut für angewandte Ökologie (2010) Globales Emissions-Modell integrierter Systeme. Version 4.5.

[9] Schnell, R. (1999) Methoden der empirischen Sozialforschung. München.

[10] Gebhardt, H., Glaser, R., Radtke, U. and Reuber, P. (2007) Geographie. Physische Geographieund Humangeographie. München. 